\title{
Detecting Land Use Modification and Its Influence on Resident Communities
}

Tesfahun Endalew ( $\nabla$ tesfayedri@gmail.com )

Salale University

Research

Keywords: Acacia Decurrens, Tree Plantation, Land Use, Change Detection, Supervised Classification

Posted Date: September 14th, 2020

DOI: https://doi.org/10.21203/rs.3.rs-71557/v1

License: (9) This work is licensed under a Creative Commons Attribution 4.0 International License. Read Full License 


\section{Abstract}

The study intended to detecting the land use land cover changes, trends and their magnitude between 1986 and 2019 years by using GIS and remote sensing in Fagita Lekoma District, Amhara region, Ethiopia. Three satellite data set of Landsat Thematic Mapper for 1986, Enhanced Thematic Mapper Plus for 2002 and Operational Land Imager for 2019 were used generate land use and land cover maps of the study area. Post classification comparison changed detection method was employed to identify gains and losses between Land Use Land Cover classes. Socioeconomic survey, key informant interview and field observation were also used conclude the encouragement of land use /land cover change in the study area. The result shows that cultivated land and wetland similarly decline in the entire study periods. In the 33 years, forest lands expanded by upon $200 \%$ of the original forest cover what was existed on the base year. Whereas, a result of the socioeconomic analysis the expansion of Acacia decurrens tree plantations and agricultural land are main causes of land use land cover change in the study area. The impact of this land use land cover change is more significant on the livelihood condition and status of the study area. The land use system of the study area highly converted cultivation land into forest/tree plantation. Mainly, the expansion of Acacia decurrens tree plantation on farmland is increasing the income of local residence when compare with the previous living condition in the study area.

\section{Background}

Global land use and land cover has significantly changed from the past decades. Historically, the driving force for the majority of land use land cover change is population growth, although there are several interaction factors involved. The growing population has increased demand for land, trees, and water, which, coupled with tenure insecurity or the absence of clear property rights, has resulted in the overexploitation of these natural resources, and this in turn has threatened the sustainable development of agriculture, forestry, and livestock sectors (Dean, 2003).

There were significant global historical changes in LULC between 1700 and 1990, when the area of cropland expanded from about 3.5 million $\mathrm{km}^{2}$ to some 16.5 million $\mathrm{km}^{2}$ (Lambin \& Geist, 2002). Even though the net loss of the global forest area had reduced significantly due to a large scale of afforestation reported in some countries, such as China and Vietnam, tropical deforestation has continued into the $21^{\text {st }}$ century, the world was the past (2000/2005) experienced about 0.073 million $\mathrm{km}^{2}$ of net annual deforestation, largely due to agricultural expansion (FAO, 2010). It was experienced in feature of the poorer countries and the average annual deforestation rate, between 1990 and 2005, in low income countries was $0.5 \%$ while deforestation is lower ( $0.2 \%)$ in middle income countries (World Bank, 2007).

Of course agricultural activities in sub-Saharan Africa are dependent on variable climate and land use land cover change. In addition to this, farmers in Africa live on small hectare of farmland so it creates a great opportunity to divert one land use system to another. Decimation of farm size accelerates and hence obstacle efforts to increase farm productivity. Therefore, in line with augmenting agricultural productivity, looking for other way out has been put forward as an equally potent strategy for addressing household food security (Briassoulis, 2019). Through time such changes have beneficial while inversely they have had detrimental and adverse impacts on the environment and people's economic activities (Briassoulis, 2019). Studies of rates, patterns, and implications of LULC dynamics at local level can help to design appropriate land management practices, strategies and policies (Daniel, 2008). Gathering information about Land Use Land Cover changes is fundamental for a better understanding of the relationships and interactions between humans and the natural environment. Remote sensing data have been one of the most important data sources for studies of LULC spatial and temporal changes (Mesfin, 2016).

Land use change status was happened through time processes. Then this change has impacts on livelihood of the people and environmental condition (Daniel, 2008). In the study area the recent history through the intervention of government and the intentionally of communities started to cover their land by vegetation especially Accacian decurrens and Eucalyptus tree plantation as local people investment at the district level. These expansions of tree plantation taken as the initial issue of land use land cover change and have impacts on the socioeconomic activities of the local people. Therefore, this study analyses historical patterns of land use/cover and consequences that occurred between over a period of three decades (1986-2019) in the study area.

\section{Methods And Materials}




\section{Geographical location}

Fagita Lekoma district is one part of the Awi Zone in Amhara region Northwestern of Ethiopia. Fagita Lekoma is bordered on the south by Banja Shekudad, on the west by Guangua, on the north by Dangila, and on the east by the Mirab Gojjam Zone. Towns in Fagita Lekoma include Addis Kidam and Fagita Lekoma woreda is located between $10^{\circ} 57^{\prime} 23^{\prime \prime}-11^{\circ} 11^{\prime} 21^{\prime \prime}$ North latitude and $36^{\circ} 40^{\prime} 01^{\prime \prime}-37^{\circ} 05^{\prime} 21^{\prime \prime}$ longitude, in Awi Zone of Amhara National Regional State. It is situated about $460 \mathrm{~km}$ northwest of Addis Ababa and $100 \mathrm{~km}$ southwest of Bahir Dar, the capital city of Amhara regional state.

\section{Data acquisition and image classification approach}

In order to cover the intended period of study, different types of imageries originating from different types of sensors were used. The images were obtained from United States Geological Survey (www.USGS.gov).

\begin{tabular}{|lllllll|}
\hline Data type & Year & $\begin{array}{l}\text { Data acquisition } \\
\text { Months }\end{array}$ & Sensor & Path and Row & Resolution & Source of data \\
\hline Landsat & 1986 & Jan 01 & ETM & $170 / 52$ & $30 M$ & USGS \\
\hline Landsat & 2002 & Jan 05 & ETM+ & $170 / 52$ & $30 M$ & USGS \\
\hline Landsat & 2019 & Jan 16 & OLI & $170 / 52$ & $30 M$ & USGS \\
\hline
\end{tabular}

Tabe.1 The satellite data source characteristics

Images from different time periods were used for the classification of LULC of the study area. That is multi temporal raw satellite data has been imported to Erdas Imagine 2010 image processing software. Image processing consists of processes aimed at the geometric and radiometric correction, standardization of imagery to improve our ability to interpret qualitatively and quantitatively image components. Since the United States Geological Survey (USGS) freely offers the Landsat Orthorectified data which consists of a global set of high-quality, relatively cloud-free Orthorectified TM, ETM+ and OLI imagery therefore there is no need for geometric correction but check the position. After all, land use land cover change maps and land cover statistics were generated to compare the temporal change of the study area for the past three decades by using ArcGIS 10.4 and ERDAS Imagine 2010 integrally.

\section{Development of a Classification Scheme}

Based on the prior knowledge of the study area and a brief reconnaissance survey a classification scheme was develop for the study area as following in the table 2 Based on definitions of LULC types given above are a modification of Anderson's classification scheme in 1976.

\begin{tabular}{|c|c|}
\hline $\begin{array}{l}\text { LULC } \\
\text { class }\end{array}$ & Description \\
\hline $\begin{array}{l}\text { Cultivated } \\
\text { land }\end{array}$ & $\begin{array}{l}\text { Includes annual rain fed and irrigated cultivation. Lands mostly used for cereal production in subsistence } \\
\text { farming and mixed with bushes. }\end{array}$ \\
\hline Grassland & Predominantly covered by small grasses with a small proportion of shrub and trees. \\
\hline $\begin{array}{l}\text { Tree } \\
\text { plantation }\end{array}$ & $\begin{array}{l}\text { Includes densely growth trees forming closed canopy. The predominant species are Bahirzaf (Eucalyptus tree), } \\
\text { Chigegn (Acacia decurrens) and Kerkeha (Arundinaria alpine) or Bamboo forest. Note that, sparsely natural } \\
\text { forests which are found in the study area including under tree plantations. Because which haven't a known ratio } \\
\text { to differentiate from one others. }\end{array}$ \\
\hline Wetland & $\begin{array}{l}\text { Represents most plains areas with frequent flooding event during the rainy season and water table is at, near, or } \\
\text { above the land surface for a significant part of most years. }\end{array}$ \\
\hline settlement & Area occupied by small town and settlement including market places, roads, and institution \\
\hline
\end{tabular}

Table 2 the land use land covers class and their descriptions. 


\section{Methods of Supervised Classification and Data Analysis}

To perform the classification the maximum likelihood supervised classifier was employed. Training areas for all spectral classes were developed composing each information class to be identified by the classifier. Since there was more than one spectrally different signature found for each information class. The researcher used more than thirty training samples for each classification. A recode function was used to merge spectrally different classes to generate final information classes.

The post classification approach was used for mapping detailed LULC determination. This approach is generally considered the most obvious approach to change detection. It requires the comparison of independently classified images of the same study area acquired over two different time periods. One advantage of using post-classification change detection is that data normalization for atmospheric and sensor differences between two date is not required, since images acquired for two dates are classified separately (Singh, 1989). Change statistics were computed by comparing values of area of one data set with the corresponding value of the second data set in each period. Percentage change to determine the trend of change can then be calculated by dividing observed change by sum of changes multiplied by 100 (Puyravaud, 2003).

\section{Percentage of change (trend) $=\frac{\mathbf{x}-\mathbf{y}}{\boldsymbol{y}} \boldsymbol{x} 100$ where $\mathrm{X}=$ recent (later) area of land use land cover. $\mathrm{Y}=$ Previous (initial) area of land use/land cover (Puyravaud, 2003).}

\section{Rate of change in percent $=\frac{\text { observed change between two maps }}{\text { rate of time intervals }} \times 100$}

\section{Results And Discussion}

Cultivated land, grassland, wetland, forest and urban area are the major LULC classes for the study area and periods.

The classification result of the 1986 image revealed that cultivated land constituted the largest proportion of land in the woreda with a value of ( $31037.4 \mathrm{ha}$ ) $45.82 \%$ followed by grassland which accounts for ( $28104.12 \mathrm{ha}$ ) $41.49 \%$. Tree plantation/forest and wetland were constituted $9.1 \%$ and $3.5 \%$ respectively. And there was smallest settlement area during these period which covers 85 ha $(0.13 \%)$. As shown in Figure 3 on the 2002 image of the district, the proportion of land allocated for cultivation increasing to ( 35152.56 ha) $51.89 \%$. Furthermore, grassland was decreased and covered (22535.28 ha) $33.26 \%$ of the district. However, as compare to the base year of 1986, the proportions of tree plantation was remaining constant which accounts about (6262.74 ha) $9.24 \%$ and wetland slightly increased into (3505.86 ha) 5.17\% respectively. In figure 4 classified image of the district, compare to the base year of 1986 and 2002, the proportions of tree plantations was highly increased which accounts about (18529.11 ha) $27.2 \%$ and settlement area also increased in the past over fifteen years which accounts about (1491 ha) $2.4 \%$.

\section{Land Use Land Cover Change Map}

According to Table 3 conversion matrix for the year 1986-2019, the change in the land use land cover in the study area was by enlarge attributed to expansion of tree plantation. This class has expanded at the expense of cultivated land (7486.02 ha) about $11.1 \%$, grass land (7285.59 ha) $10.75 \%$ was shifted into tree plantation classes. There was also significant change of grassland to cultivated land in this period in 8815.5 ha $(13 \%)$ and 8588.43 ha $(12.7 \%)$ of cultivated land was also changed to grassland. Averagely, tree plantation covers showed increment in the past over three decade's period which mainly attributed to the change of cultivated land and grassland into tree plantation and settlement area respectively. 


\begin{tabular}{|c|c|c|c|c|c|c|c|c|c|c|c|}
\hline \multirow{2}{*}{\multicolumn{2}{|c|}{$\begin{array}{l}\text { Conversion matrix } \\
\text { of } 1986-2019\end{array}$}} & \multicolumn{10}{|c|}{2019} \\
\hline & & \multicolumn{2}{|c|}{ Tree plantation } & \multicolumn{2}{|c|}{ Cultivated } & \multicolumn{2}{|c|}{ Grassland } & \multicolumn{2}{|c|}{ Wetland } & \multicolumn{2}{|c|}{ Settlement } \\
\hline & & $\mathrm{Ha}$ & $\%$ & $\mathrm{Ha}$ & $\%$ & ha & $\%$ & ha & $\%$ & ha & $\%$ \\
\hline \multirow{5}{*}{$\stackrel{\circ}{\mathscr{\infty}}$} & $\begin{array}{l}\text { Tree } \\
\text { planation }\end{array}$ & 3359 & $\begin{array}{l}4.9 \\
5\end{array}$ & 867 & $\begin{array}{l}1.2 \\
7\end{array}$ & 1673 & $\begin{array}{l}2.4 \\
7\end{array}$ & 208.3 & $\begin{array}{l}0.3 \\
1\end{array}$ & 58.23 & $\begin{array}{l}0.08 \\
5\end{array}$ \\
\hline & Cultivated & 7486 & 11 & $\begin{array}{l}1398 \\
8\end{array}$ & $\begin{array}{l}20 . \\
6\end{array}$ & 8588.4 & $\begin{array}{l}12 . \\
6\end{array}$ & 101.5 & $\begin{array}{l}0.1 \\
5\end{array}$ & 829.62 & 1.22 \\
\hline & Grassland & 7286 & $\begin{array}{l}10 . \\
8\end{array}$ & 8815 & 13 & 11097 & $\begin{array}{l}16 . \\
4\end{array}$ & 299.3 & $\begin{array}{l}0.4 \\
3\end{array}$ & 566.3 & 0.83 \\
\hline & Wetland & 313.3 & $\begin{array}{l}0.4 \\
6\end{array}$ & 830.7 & $\begin{array}{l}1.2 \\
2\end{array}$ & 949.8 & 1.4 & 276 & $\begin{array}{l}0.4 \\
1\end{array}$ & 32.3 & $\begin{array}{l}0.04 \\
7\end{array}$ \\
\hline & Settlement & 0 & 0 & 12 & $\begin{array}{l}0.0 \\
1\end{array}$ & 0 & 0 & 0 & 0 & 73 & 0.12 \\
\hline
\end{tabular}

Note: Figures in Bold number represent LULC that showed no change.

Therefore compare this result in 1986-2019 satellite image analysis, the trend of change was forest land, and settlement patterns were increased on the other hand cultivated land, grassland and wetland land use classes were also decreased. However, still now cultivated land has cover the dominant range of land in the study area. Whereas, survey data indicated that forest resources are highly increased. Table 3 Post-classification Matrix of Study Area 1986-2019.

\section{Trend and Rate of Land Use Land Cover Change}

An important aspect of change detection is to determine what is actually changed to what i.e. which land use class is changing to which other classes (Abiy, 2014). This information reveals both the changes (additions and reductions) and classes that are relatively stable overtime. This information will also serve as a vital tool in management decisions.

Table 4 shows that the pattern of changes in LULC between 1986 and 2019. Land used for cultivated land decreased by $21 \%$ compared with the previous amount of cover. Grassland and wetland showed similar patterns of change, with decreases of $20 \%$ and $63 \%$ respectively in the last three decades. In contrast, tree plantation cover showed a reverse trend, increasing by $200 \%$ during the same period of time. Settlement area was showed a similar pattern of change and increased by $1654 \%$ in this period. In contrast, more and more cultivated land and grassland were became decreasing their cover in compared to the previous time and replaced into tree plantation and settlement area.

Table 4 Pattern of LULC changes between 1986 and 2019 in the Fagita Lekoma District.

\begin{tabular}{|c|c|c|c|c|c|c|c|c|c|c|c|c|}
\hline \multirow[t]{2}{*}{$\begin{array}{l}\text { LULC } \\
\text { classes }\end{array}$} & \multicolumn{2}{|c|}{ Area 1986} & \multicolumn{2}{|c|}{ Area 2002} & \multicolumn{2}{|c|}{ Area 2019} & \multicolumn{2}{|c|}{$\begin{array}{l}\text { Change } \\
\text { between } \\
\text { 1986_2002 }\end{array}$} & \multicolumn{2}{|c|}{$\begin{array}{l}\text { Change between } \\
\text { 2002_2019 }\end{array}$} & \multicolumn{2}{|c|}{$\begin{array}{l}\text { Change between } \\
\text { 1986_2019 }\end{array}$} \\
\hline & $\mathrm{Ha}$ & $\%$ & $\mathrm{Ha}$ & $\%$ & $\mathrm{Ha}$ & $\%$ & $\mathrm{Ha}$ & $\%$ & $\mathrm{Ha}$ & $\%$ & $\mathrm{Ha}$ & $\%$ \\
\hline $\begin{array}{l}\text { Tree } \\
\text { Plantation }\end{array}$ & 6181.56 & 9.1 & 6262.7 & 9.24 & 18529 & 27.2 & +81.2 & +1.3 & +12266 & +196 & +12345 & +200 \\
\hline Cultivated & 31037.4 & 45.8 & 35152 & 51.9 & 24641 & 36.3 & +4115 & +13 & -10511 & -33 & -6392 & -21 \\
\hline Grassland & 28037.1 & 41.5 & 22535 & 33.2 & 22405 & 33 & -5569 & -20 & -130.3 & -0.6 & -5699 & -20 \\
\hline Wetland & 2410 & 3.5 & 3506 & 5.1 & 888 & 1.3 & +1097 & +46 & -2618 & -75 & -1522 & -63 \\
\hline Settlement & 85 & 0.13 & 280.8 & 0.41 & 1491 & 2.4 & +196 & +231 & +1210 & +431 & +1406 & +1654 \\
\hline
\end{tabular}

N.B '-' indicates decrease ' + ' indicates increase 'ha' indicates hectares 
Cultivated land constituted $45.82 \%, 51.89 \%$ and $36.3 \%$ in the years 1986, 2002 and 2019 respectively. The still now a day predominance of cultivated land in the area agrees with the findings of Tegegne (2002), in Derekolli Catchment, South Wollo, Solomon (2005), in Headstream of Abay watershed and Gete and Hurni (2001) in Anjeni area of north western Ethiopian highlands. The findings of Woldeamlak (2002), in the same Region, for Chemoga Watershed Blue Nile Basin, Ethiopia, between 1957 and 1998 was a similar expansion and shrinking pattern of cultivated lands by $13 \%$ increase in 1957-1982, while 2\% decrease in 1982-1998. Aggregately cultivated land about 6396.2 ha (20.6\%) was losing into forest and settlement area. However, still now a day cultivated land is the cover the largest parts and the basic socioeconomic activities in the study area.

\section{Grassland}

In the three decade years, this category was expanded by over $41.4 \%$ (28063.4 ha) of the original grassland cover which existed at the base year. Between 1986 and 2019, almost $31 \%$ of grassland cover was obtained from cultivated lands. This indicates that when the farmers fallow their farm land they use it as a grazing for their cattle. It is easy to convert a given land between these class categories even within year. During the overall increasing period (1986-2019), the conversion of wetland into grassland accounted for $39.5 \%$ of the total gained grassland. In the same period, this category also gained $27.1 \%$ of its areal extent from the removal of trees. This finding disagrees with that of Gete and Hurni (2001) and Solomon (2005), who indicated an increase of grassland cover in Anjeni area and Headstream of Abay Watershed respectively, both in northwest Ethiopia. On the other hand, agrees with the find of Daniel (2008), Shrub-grasslands was showed a similar pattern of change and decreased by $61 \%$ in between 1972 and 2004 in the Upper Dijo River catchment. And Woldeamlak report (2002), which showed a decrease of this land cover type in Chemoga watershed, between 1957 and 1998. Discussions with elders and officers in FLWARDO revealed that the major reason for the decreasing of grassland was the increment population number in the area. The afforestation programs in the study area contributed its share for the reduction of grassland during the three study period, which are as much as 7285.59 ha (10.75\%). The farmers are giving more attention for covering of their land by trees because of its economic advantage when compared to the merit obtained from animal rearing.

\begin{tabular}{|c|c|c|c|c|c|c|c|c|c|c|c|c|}
\hline \multirow[t]{2}{*}{$\begin{array}{l}\text { LULC } \\
\text { classes }\end{array}$} & \multicolumn{2}{|c|}{$\begin{array}{l}\text { Change } \\
\text { between } \\
\text { 1986_2002 }\end{array}$} & \multicolumn{2}{|c|}{$\begin{array}{l}\text { Annual rate of } \\
\text { change (1986- } \\
\text { 2002) }\end{array}$} & \multicolumn{2}{|c|}{$\begin{array}{l}\text { Change } \\
\text { between } \\
\text { 2002_2019 }\end{array}$} & \multicolumn{2}{|c|}{$\begin{array}{l}\text { Annual rate of } \\
\text { change ( } \\
\text { 2002_2019) }\end{array}$} & \multicolumn{2}{|c|}{$\begin{array}{l}\text { Change between } \\
\text { 1986_2019 }\end{array}$} & \multicolumn{2}{|c|}{$\begin{array}{l}\text { Annual rate of } \\
\text { change (1986 } \\
-2019)\end{array}$} \\
\hline & ha/y & $\%$ & ha/y & $\%$ & ha/y & $\%$ & ha/y & $\%$ & ha/y & $\%$ & ha/y & $\%$ \\
\hline Plantation & +81.2 & +1.3 & +5.1 & +0.08 & +12266 & +196 & +818 & +13 & +12345 & +200 & +398 & +6.4 \\
\hline Cultivated & +4115 & +13 & +257.2 & +0.83 & -10511 & -33 & -701 & -2 & -6392 & -20.6 & 2006.2 & -0.7 \\
\hline Grassland & -5569 & +19 & -345.1 & -1.24 & -130.3 & -0.6 & -8.7 & -0.04 & -5699 & -20.4 & -183.8 & -0.05 \\
\hline Wetland & +1097 & +46 & +68.6 & +2.85 & -2618 & -75 & -175 & -5 & -1522 & -63.2 & -49.1 & -2.1 \\
\hline Settlement & +196 & +131 & +12.3 & +14.5 & +1210 & +431 & +81 & +28.7 & +1406 & +1654 & +45.4 & +53.4 \\
\hline
\end{tabular}

Table 5 Annual rates of land use land cover change in Fagita Lekoma district.

N.B '-' indicates decrease ' + ' indicates increase 'ha' indicates hectares ' $y$ ' indicates year

\section{Wetland}

Wetland is the second smallest land cover type in the study area, it was about 2402.01 ha (3.5\%) in 1986 but increasing into 35012.4ha (5.41\%) in 2002 and again decreasing into 963.63 ha (1.43\%) in 2019. Of the total wetland cover in the base year, only 275.94 ha (11.9\%) remained in this category, while $40 \%, 34.6 \%, 13.1 \%$ and $1.5 \%$ was converted into grassland, cultivated land, forest and settlement respectively in all periods considered. While wetlands may be the most productive of ecosystems on earth, they are also the most threatened. Wetland destruction and alteration has been and is still seen as an advanced mode of development, even at the government level (Abebe and Gaheb, 2003). The area is the only part that represents the wetland class currently and its areal extent reduced when compared to the previous image results. 


\section{Tree plantation (Forests)}

The average rate of change tree plantation cover was showed relatively constant or no more change between 1986 and 2002 (first period) which accounts about 5.1 ha/yr. (0.08\%) added on the previous, and highly increased between 2002 and 2019 (second period) which accounts about 817.7 ha/year (13.1\%) and 1986 and 2017 (the overall study period) was similarly to the first and second study period which was increasing about 398 ha/year (6.4\%). In 1986 the area under tree plantation cover was 6181.56 ha (9.1\%) of the study area which increased into 6262.7 ha $(9.24 \%)$ in 2002.

In the total tree plantation cover in 1986, about $36.7 \%$ was converted into cultivated land, $6.9 \%$ into wetland and $5.1 \%$ into grassland in 2002. Greater than half about $51.3 \%$ was the original area remained in the same category to forest. The transformation of forest land throughout the study period was due to an increasing demand for cultivated land and grassland. That is why a large proportion of the transformed land, i.e. around $43.3 \%$ of the tree plantation cover was changed into the two classes. According to the local elders the little existing remnants of natural forests on the first study period were protected by local communities. Up until now, these forests have carried the name of local leaders in the past. Even if, it is difficult to avoid deforestation of natural forests totally in the area, recently the concerned government bodies in collaboration with the local community are trying to protect.

The major change on tree plantation between 2002 and 2019 has been basically characterized by introduction of Acacia decurrens and increasing of Eucalyptus trees. According to the Fagita Lekoma Woreda Land Administration and Registration Office (2019) explained that "partly attributed of the change in state policy in 1997 to rights of disposal of individually owned trees and to the increase in seedling availability. Two agricultural centers were established and started provision of different seedling without any cost and with little charge on some of them. Many types of seedlings were provided at a time, and Acacia decurrens have gotten a wide acceptance. This is because of its match with the degraded soil, high growth rate; wanted for charcoal production and the ability revive the fertility of soil. After cutting the Acacia decurrens trees farmers plow this land and they are obtaining good crop products". In another way the explanation of elders people "by keeping the idea of local land administrator a bout expansion of tree plantation and good crop products. The only increasing the crop product in single plot of land compare to the previous time. However highly decreasing the cultivated land due to the replacement of forest resources. Generally, crop cultivation was became too decreased in the past 15 years by the means of forest as the new livelihood activity in the study area.

\section{Settlement Area}

Addis Kidam town, almost at the center of the woreda, is part of the study area. Even if there is information from the elders about the existence of the town in 1986 as the smallest village, it has smallest sign of town on the Landsat image. This is because the houses at a time were corrugated steels and huts that make the reflectance similar with other LULC classes. Surprisingly, the size of this town had been changed during the second study period and on the 2018 the Small towns like Fagita, Segila, Gezehera, Wazina, Ashewa afri and Chguali which are located on all direction around of Addiskdam.

In the 1986 study period the settlement area covers about 85 ha (0.13\%). And also in the 2002 middle study period area covered by settlement was 280.8 ha $(0.41 \%)$ and 1491 ha $(2.4 \%)$ of the study area in 2019 . The land use and land cover change between on the first study period (1986-2002) settlement area were the class which have been expanded on cultivated land and grassland respectively. And 2019 showed that about 893.5 ha of the net gain of urban area was due to the conversion of cultivated land. The remaining 454 ha and 96.7 ha were obtained from grassland and forest respectively. As focus group discussants replied that, around Addis Kidam town basically there was a community grazing land. When the town expands this area was distributed to the community and converted to built-up areas.

\subsection{Implication of land use change}

The socioeconomic activities like crop production, animal husbandry, and charcoal production of an area are playing an important role on the land use type of the area. In other way the changes in land use directly or indirectly affect the socioeconomic of a given society. The changes discussed from the period (1986-2018) remote sensed image classification the one which had more effect on the economic condition of the inhabitants is the change in relation to forest cover. According to the firsthand information 
obtained from the interviewees in FLWARDO, almost $90 \%$ of the woreda population is now directly or indirectly relate with the production of Acacia decurrens and its effects. On both rural and urban parts of the study area the communities are producing Acacia decurrens seedling in their compound. These created a job of them without age and sex specification. Some of these activities in relation to this are production of seedling, keeping the grown forest from cattle, cutting of it while it reached for purpose and production of charcoal.

Previously, in Fagita Lekoma Woreda many youths were jobless and exposed to participate in illegal activities. But now these groups of population are working by forming three groups. The first group team covers the loaded charcoal and makes ready for transportation. The second group loads the charcoal to car. Finally the third serves as a broker to meet the buyers and sellers of charcoal. In the rural parts of the study area previously most of the young populations were employed as a servant within and out of the woreda; migrate to Addis Ababa and different parts of the country. Now a day thanks to this golden kind of forest this is becoming a history, they are engaged with starting from the production of seedling to the production and provision of charcoal which enables to lead a better life in their birthplace. Such a kind of activities requires large labor force because they are wide and continues throughout the year.

Females also participate basically on preparation of the inputs to produce seedling, watering the seedling and the transportation of the charcoal product from inaccessible areas. In general Acacia decurrens is serving as a cash crop in the woreda. For example, as indicated from the report of Fagita Lekoma Woreda Revenue Office in 2019 (2011 E.C. budget year) the woreda obtained more than 11 million ETB from the exported charcoal as royalty tax. Now the woreda is one of the major providers of charcoal to Addis Ababa city's population and other parts of the country.

The government employees and merchants are also the beneficiaries of this land use change. Being a government employee at woreda level and having a car is very difficult really now. But who were government employees could do this by changing their job to trading charcoal. Before the past ten and fifteen years almost all of the rural residents of the study area were inhabited in huts

and looking steel houses was endemic. Now a day in order to have such asset having land by itself is enough. Those farmers who haven't the capacity to cultivate their land can rented to somebody and utilize it. Now the majority of the rural population leaves in steel houses and they are also constructing additional homes at urban areas. In addition the farmers are learning technical way of using their land like generating two purposes from a given land at the same time. When they need to grow the Acacia decurrens they plow the land and grow with the crop together. After two and three years they use the grass inside for their cattle's as a food source. So, the land which is covered by this type of forest becomes out of such additional advantages not more than four and five years. When the forest becomes from four to six years old, it will be removed to produce charcoal and replaced by another.

Despite the above mentioned advantages, due to the land use change in general, the expansion of forest in particular the farmers are facing problems like shortage of productive farmland and grazing lands. These are more shown the existence of importing cereals for consumption. There are also farmers who exposed to different social and economic problems by renting almost all of the land they have. The other problems facing the productive cultivated land should automatically replace by forest resource due to this case the next few years the demand of food consumption will be diminishing to serve the study area.

To generalize depend on data obtained from surveyed household; land use change on expansion of forest land has positive impacts on economic, social and environmental perspective. In the perspective of economic, it can increase the income of local society, increasing royal tax of the government, reduce jobless youths and create job opportunity in the study area and socially, acceptable the benefits of forest resources for charcoal production, construction materials and energy source. And environmentally, it increases soil fertility, productivity and it serves as soil conservation because Acacia decurrens tree is growing any up and down area as suitable land in the study area. On the other hand it has negative impacts that are natural forest degradation, loss of productive land and communal land.

\section{Conclusion And Recommendation}

This study has revealed that the recent advancements in spatial technology, namely remote sensing and GIS, could provide powerful tools for evaluating land use and land cover changes at woreda levels. The results of this study revealed the existence of significant land use and land cover changes in the last 32 years. Especially the expansion of tree plantations on cultivated land.

Page $8 / 13$ 
Results showed the changes in the last 33 years, forest land shows increase $(+200 \%)$ while cultivated land have shown a significant decrease in area (-20.6\%) in the study area. The rest Grass land, settlement area and wetland show decrease to $-20.4 \%$, increase to $+1654 \%$ and decrease to $-63.2 \%$ respectively for the whole period. Accordingly, the $1986-2002$ change analysis showed high change in land use land cover that was cultivated land increased to $+13 \%$, wetland increase to $+46 \%$ forest increase to $+1.3 \%$ while $2002-2019$ changed analysis showed that relatively changes from cultivated land highly decreased by $-75 \%$ and forest increased by $+196 \%$.

Therefore the area of land under tree plantation has increased; there should be an appropriate land use planning and policy with impact studies and scenarios, in order to use a given land with its maximum output. In addition the farmers should be aware of their land use system. Because they are covering their land with Acacia decurrens only by considering the money that will be obtained from charcoal product after four to six years. This activity is shown sometimes even on irrigable lands which can give merit twice a year. So, when farmers need to cover their land by Acacia decurrens the concerned government body should approve as the land is not productive for crop cultivation. Such policy also will be enabling to identify the proper land for specific purpose so that the marginal lands like wetland will not be put into use. And to make the woreda community more profitable, the charcoal production system should be supported by results of modern technology. Because the communities are practicing traditional way

of charcoal production system still now and during this process there are woods that will be changed to ash and the producers are also exposed to health problems.

\section{Abbreviations}

ERDAS : Earth Resource Data Analysis System

FAO : Food and Agricultural Organization

FLWARDO : FagitaLekomaWoreda Agriculture and Rural Development Office

GIS : Geographic Information System

LULC : Land Use Land Cover

OLI : Operational Land Imager

USGS : United States Geological Survey

\section{Declarations}

\section{Not Applicable}

\section{- Ethics approval and consent to participate}

\section{Not applicable}

\section{- Consent for publication}

- Availability of data and materials

The datasets generated during and/or analyzed during the current study are available from the corresponding author on reasonable request.

\section{- Competing interests}

The author declares that they have no competing interests.

\section{- Funding}

The author received no financial support for the research, authorship, and/or publication of this article. 


\section{- Author contribution}

Tesfahun Endalew has made large contribution starting from the designation of this research, acquisition of data, data collection, entry, coding and analysis, interpretation of the results and discussions. Even, make a lot of times to critical revision of my paper issue and leading the overall activities of this research.

\section{- Acknowledgements}

The authors gratefully acknowledge to Fagita Lekoma district communities also deserve appreciation for their kind response to any requested information.

\section{- Author information}

Tesfahun Endalew is Lecturer at Salale University, College of Social Sciences and Humanities, Department of Geography and Environmental Studies, (tesfayedri@gmail.com). P.O. Box 245, Fiche, Ethiopia.

\section{References}

1. Anderson, J. R. (1976). A land use and land cover classification system for use with remote sensor data (Vol. 964). US Government Printing Office. 2. Briassoulis, H. (2019). Analysis of land use change: theoretical and modeling approaches. 3. Daniel, A. (2008). Remote sensing and GIS-based land use and land cover change detection in the Upper Dijo river catchment, Silte Zone. Southern Ethiopia. Working papers on population and land use change in central Ethiopia, Addis Ababa University. 4. Dean, A. M., \& Smith, G. M. (2003). An evaluation of per-parcel land cover mapping using maximum likelihood class probabilities. International Journal of Remote Sensing, 24(14), 2905-2920. 5. Food and Agriculture Organization of the United Nations. Forestry Department (Rome). (2010). Global forest resources assessment 2010: Main report. Food and Agriculture Organization of the United Nations. 6. Geist, H. J., \& Lambin, E. F. (2002). Proximate causes and underlying driving forces of tropical deforestation: Tropical forests are disappearing as the result of many pressures, both local and regional, acting in various combinations in different geographical locations. Bioscience, 52(2), 143-150. 7. Gete, Z., \& Hurni, H. (2001). Implications of land use and land cover dynamics for mountain resource degradation in the Northwestern Ethiopian highlands. Mountain research and development, 21(2), 184-191. 8. Mesfin, W. A., Assen, M., \& Nicolau, M. D. (2016). Patterns, causes and consequences of land use/cover dynamics in the Gumara watershed of Lake Tana basin, Northwestern Ethiopia. Environmental Systems Research, 5(1), 8. 9. Singh, A. (1989). Review article digital change detection techniques using remotely-sensed data. International journal of remote sensing, 10 (6), 989-1003. 10. Solomon, A. (2005). Land use and land-cover change and its environmental implications in a tropical highland watershed, Wollo, Ethiopia. Thesis Unpublished document. 11. Woldeamlak, B., \& Solomon, A. (2013). Land-use and land-cover change and its environmental implications in a tropical highland watershed, Ethiopia. International journal of environmental studies, 70 (1), 126-139. 12. Woldeamlak, B., \& Solomon, A. (2013). Land-use and land-cover change and its environmental implications in a tropical highland watershed, Ethiopia. International journal of environmental studies, 70 (1), 126139 13. World Bank, (2007). Agriculture for development. World Bank report, 2008. Washington DC.

\section{Figures}




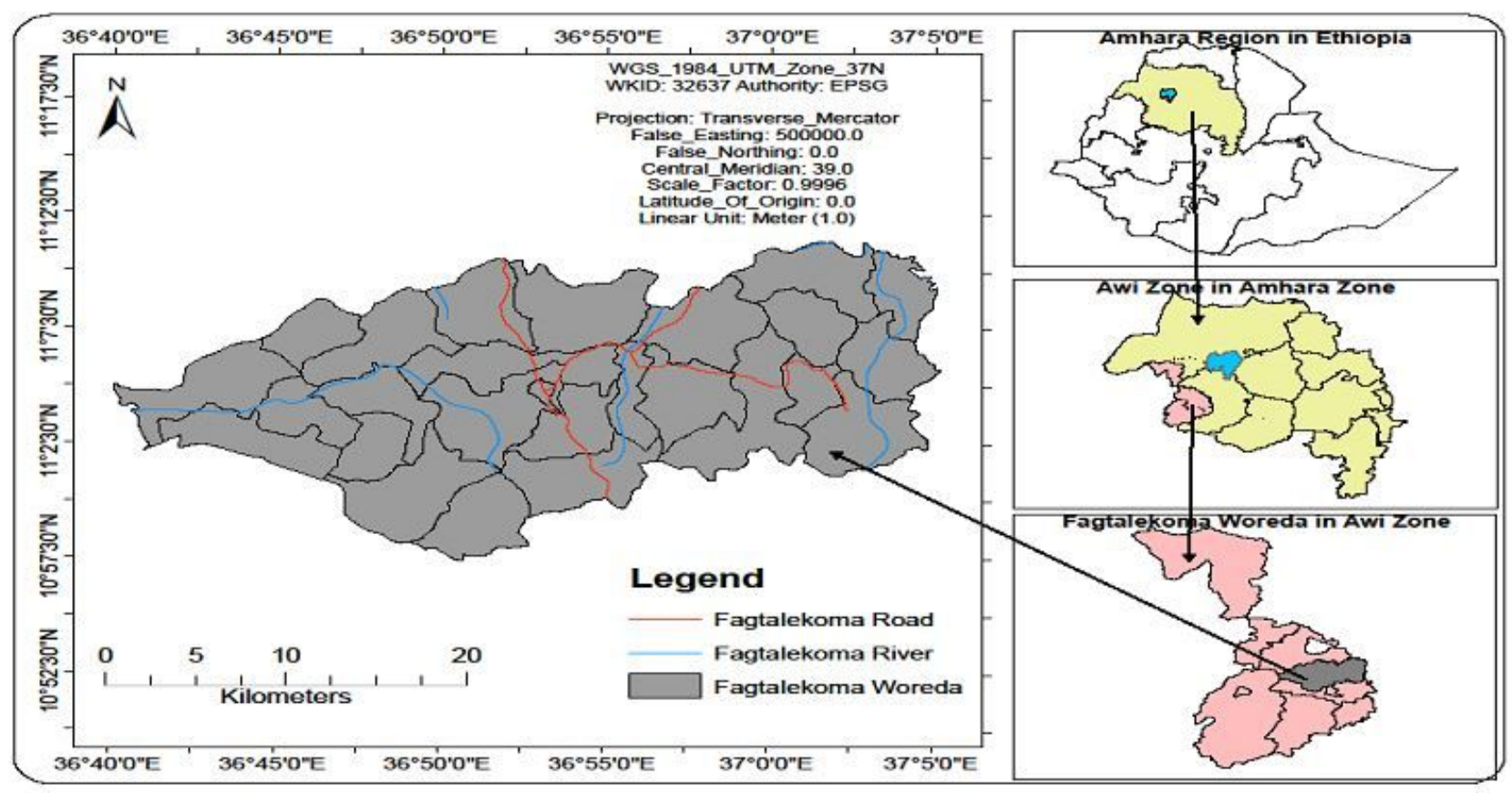

Figure 1

Location Map of Fagita Lekoma District.

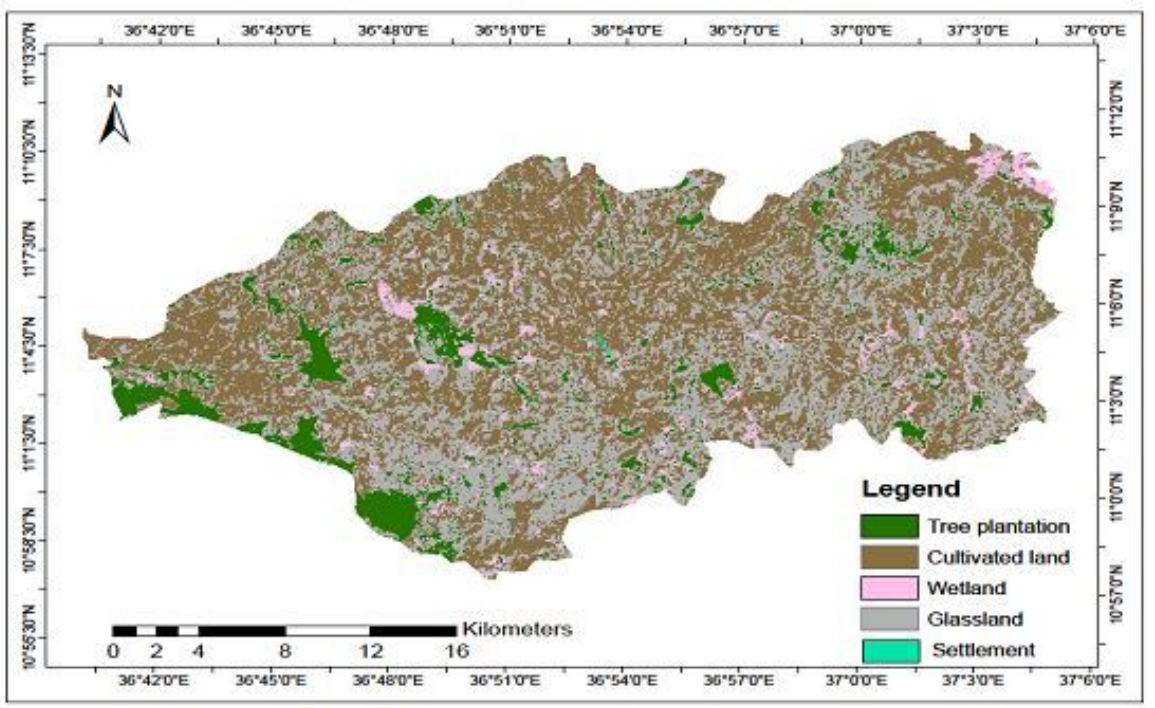

Figure 2

LULC Map of Fagita Lekoma Woreda in 1986 


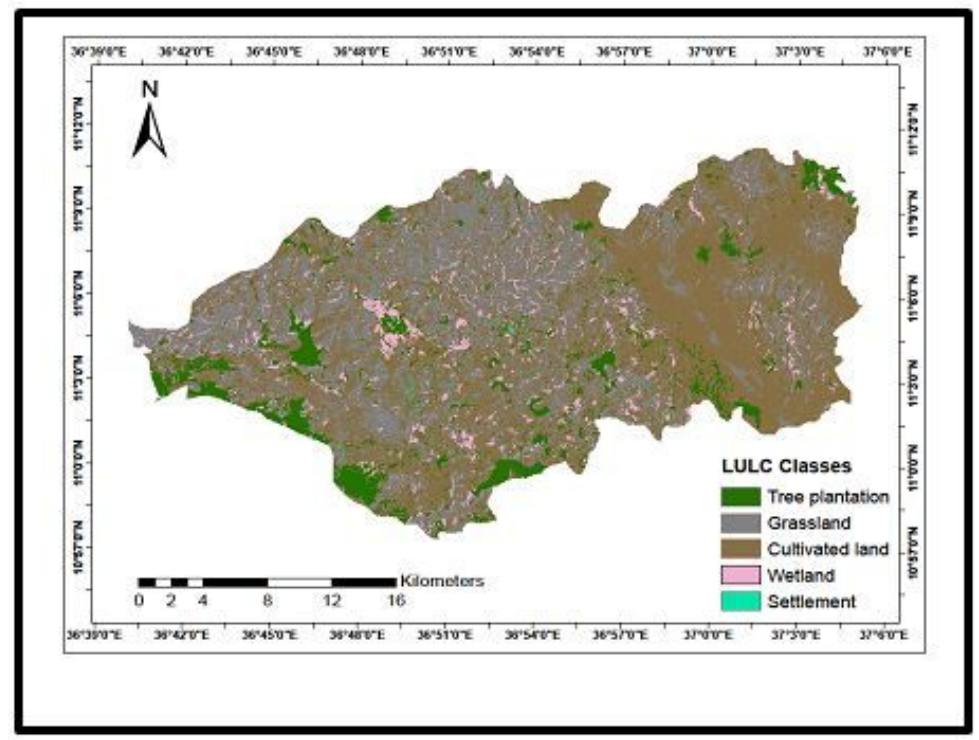

Figure 3

LULC Map 2002

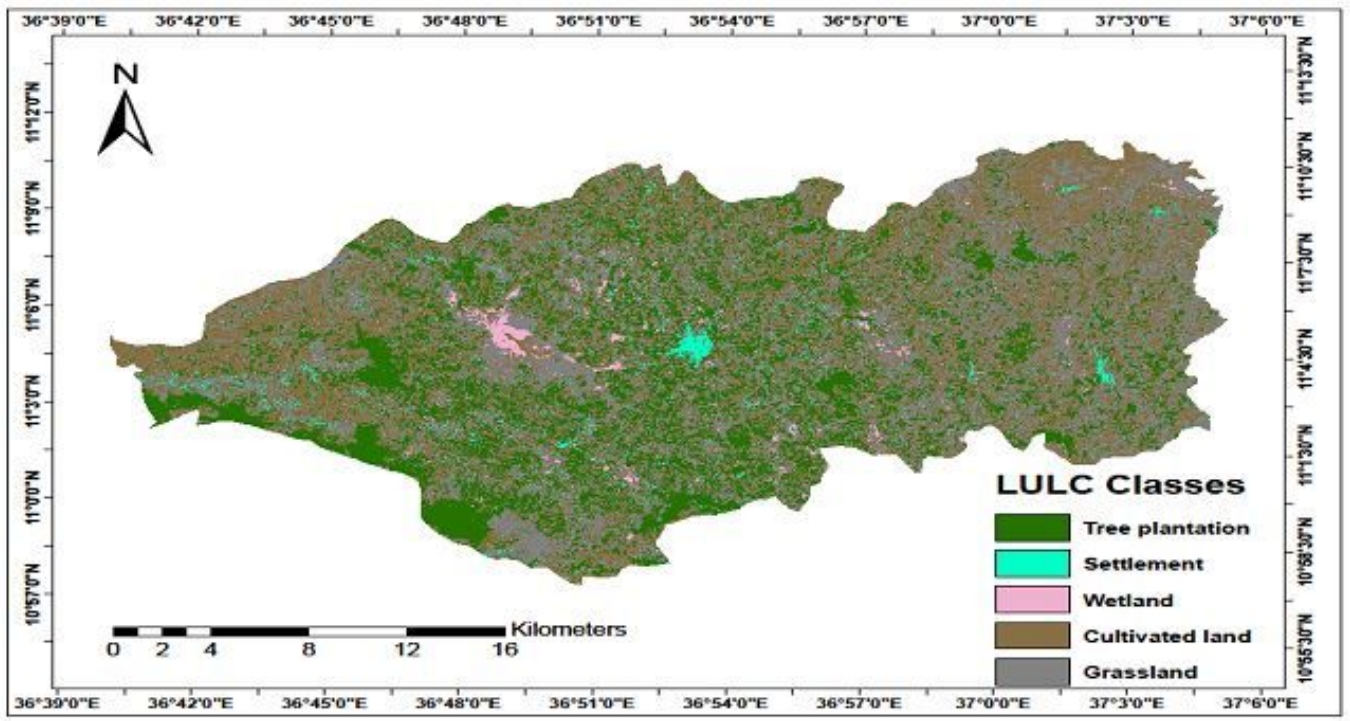

Figure 4

LULC Map of Fagita Lekoma Woreda in 2019 


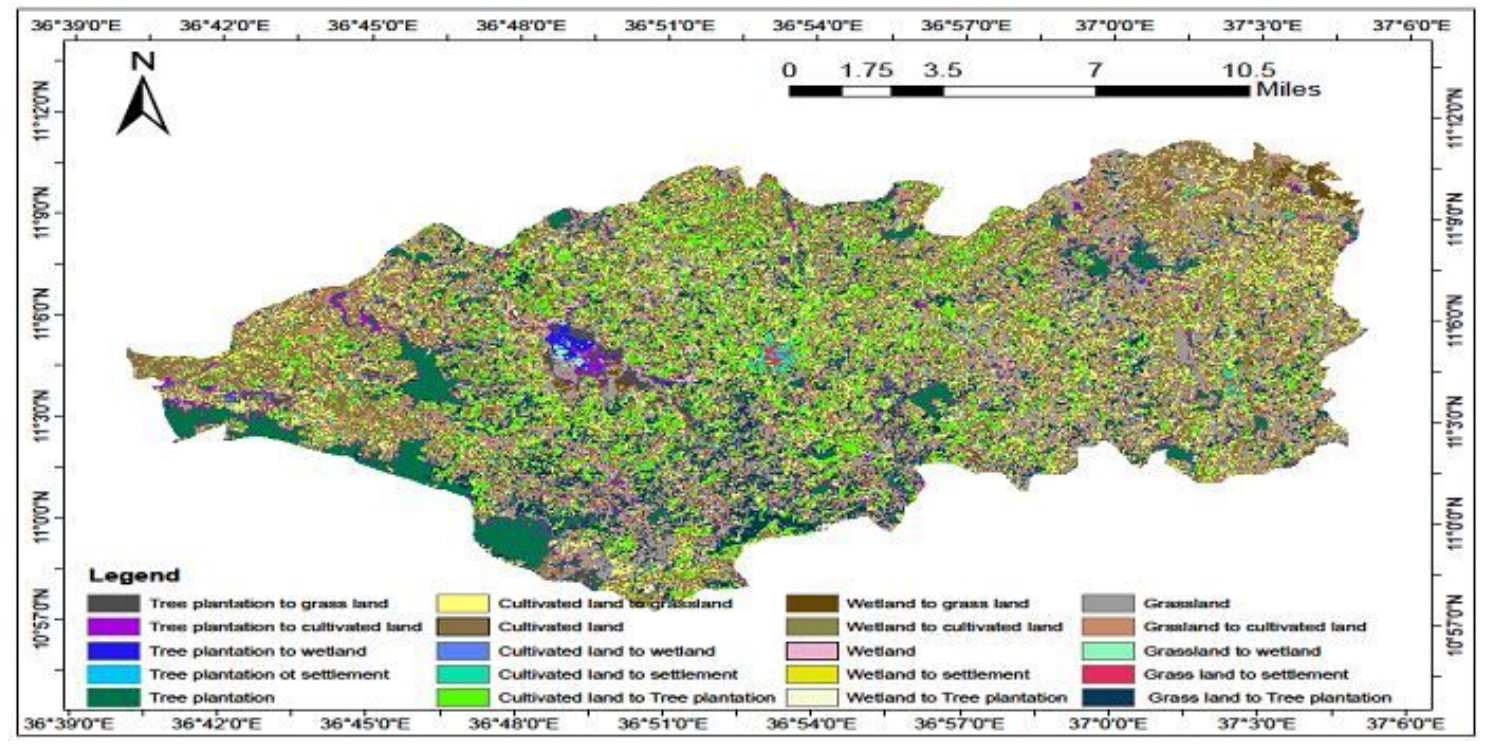

Figure 5

Land Use Land Cover Change Map between 1986 and 2019 